\title{
A Life-Cycle Perspective of Professionalism in Services
}

In this article, we develop a professional service life cycle model to describe the changes in professional work over time. We explore the drivers of these changes through an in-depth longitudinal case study of one specific professional service - Leadership in Energy \& Environmental Design (LEED) consulting. We focus on understanding the evolutionary path of LEED consulting work as a result of its knowledge base, community and response to market and technological forces. Case evidence demonstrates an inherent tension between innovation and commodification resulting from multiple demands through various developmental stages. The life cycle model has important implications for value-creation in professional service operations management. First, it broadens the theoretical investigation of professional services to consider all processes and people along the professional continuum - from most innovative to commodified. Coordinated effort along the professional continuum is the key to delivering both effectiveness and efficiency. Second, proactively managing the transitions along the evolutionary path is both possible and desirable. Standardization and specialization improves talent allocation and boosts future innovation. We suggest future opportunities to test and enrich the model. 


\section{Introduction}

Professional services constitute a major pillar in today’s knowledge economy (Drucker, 1969; Hayes, 2002), both in terms of their contribution to the economy (JOM CFP "Professional Service Operations Management,” Lewis et al., 2013) and their fast growth (Goodale et al., 2008). Given the rapid changes in today's business and technology environment, managing professional services is becoming increasingly difficult. These changes are not new; they are the result of forces that continuously shape the services and work we consider professional. Take law, a widely-studied professional service. The unrelenting decline in law school enrollment and the dismal career prospects of law graduates in the US has made headlines for some time (Bronner, 2013; Olson and Segal, 2014). Law scholars have pointed to two primary forces driving these changes: (1) continuously decreasing knowledge barriers, facilitated by the deregulation of the profession, have allowed people with less or no legal training (e.g., paralegals or accountants) to do the work once completed by lawyers; (2) legal knowledge embedded in computer programs has reduced the need for human workers (Campbell et al., 2012; Merritt, 2015).

Professional service organizations (PSOs) are under constant pressure from value-seeking clients to provide faster, cheaper and better service (Christensen and Anthony, 2004). For instance, the Internet and Communication Technology (ICT) is transforming the nature of professional service work through sophisticated cognitive analysis of complex data (Brynjolfsson and McAfee, 2012). As a result of these market and technological forces, significant changes have been observed across the work of radiologists, pharmacists, professors, accountants and architects (Cohn, 2013; Ford, 2015; Meisenhelder, 2013).

Although research examining professional services and professions has acknowledged such change as an underlying theme (see Greenwood and Lachman 1996), the field of operations management has yet to develop models that capture these dynamics. The field has called for a deep 
understanding of professional service operations management (PSOM). Pressing issues include how technology is disrupting traditional models, the key drivers of change in PSOM, and the adaptation of professional services to different market segments (Lewis et al., 2013). Our study responds to the call by presenting a dynamic model that addresses internal and external drivers and incorporates both innovative and commodified components.

Our unit of analysis is professional service work, which consists of processes completed by individuals who apply their knowledge to solving problems for clients. Traditionally, professional service work has been characterized as highly customized with less focus on efficiency (Schmenner, 2004, 1986; Von Nordenflycht, 2010). Although this characterization may be true at the macro level, it has led to an overemphasis on high variability and customized processes in PSOM. ${ }^{i}$ As a result, less variable processes with high throughput performed within PSOs has been ignored until recently (Lewis and Brown, 2012). Although customization is partly driven by inherent variability introduced by customers (Frei, 2006), a combination of customized and standardized work performed by a team of professionals and non-professionals is in fact the primary work performed in PSOs (Christensen and Anthony, 2004; Lewis and Brown, 2012; Quinn et al., 1996). However, critical issues such as what factors drive the mix of customized and standardized work and how to manage this changing mix to maximize both efficiency and effectiveness remain unexplored. Our paper addresses these gaps by focusing on the evolution of a specific service and exploring the forces that drive the transition of professional service work from being completely new and innovative to becoming less customized and eventually commodified.

Specifically, we explore a life cycle model via a case study in the green building industry and analyze the development of Leadership in Energy \& Environmental Design (LEED) consulting 
services. PSOM research in the consulting context is growing due to the increasing dominance of knowledge intensive work (Field et al., 2012; Roels et al., 2010; Xue and Field, 2008). LEED consulting, as a new professional service that has developed over a short period of time, allows us to take a "fruit fly" (Fine, 1998) approach to examining the forces that drive the tension between innovation and commodification. This longitudinal perspective complements prior new service development (NSD) work (Froehle and Roth, 2007; Papastathopoulou and Hultink, 2012), and contributes to the integration of the literature streams on service innovation and service delivery system design (Johnson et al., 2000).

\section{Literature Review}

Carr-Sanders and Wilson (1933) defined professions as occupational groupings of experts who apply specialized knowledge to solving unique problems. Work is generally defined as activities involving mental or physical effort performed to achieve a purpose or result. We therefore define our unit of analysis, professional service work, as the set of activities performed by individuals with expertise to achieve problem solving for clients. Some examples of professional service work include consulting projects, medical procedures, and legal cases. This definition aligns with the knowledge work literature (Blackler, 1995) by emphasizing knowledge application.

Defining our unit of analysis as professional service work is important for a number of reasons. Existing service typologies define professional service in contrast with mass service (Brock et al., 1999; Lovelock, 1983; Von Nordenflycht, 2010), which has led to a static view of professional service work as highly customized and thus compromising on efficiency. However, highly customized work that is knowledge-intensive arguably exists in almost every service domain (Schmenner, 1986). Our focus on the work itself allows a longitudinal view of the system of processes completed by people with deep knowledge, such as a doctor or lawyer, as well as those 
provided by individuals who complement and assist in the delivery of these professional services. Such an approach accounts for the evolution of services from highly innovative to commodified while allowing theory building that unifies the service domain. Investigating how specific service work is completed by a changing team of individuals with varying skills over time enriches the empirical understanding of the link between performance and leveraged talent in PSOs (Hitt et al., 2001; Quinn et al., 1996) and suggests theory building opportunities at the intersection of the life cycle model and the resource-based view (Grant, 1996a, 1991; Peteraf, 1993).

\subsection{Four Major Areas of Consideration in Professional Service Work}

We identify four primary areas relevant to professional service work. These areas display varying levels of tension between innovation and commodification. This tension we propose presents both challenges and opportunities for managing professional service work. To that end, we draw on life cycle models in new service development, management and marketing literatures to inform our conceptualization of the changes in professional work over time.

\subsubsection{New Professional Service Development}

Individual creativity plays an important role in generating new ideas for conducting professional service work. Research has suggested that the intellectual resources contained within individuals are primary resources in new service development (NSD) (Edvardsson and Olsson, 1996; Froehle and Roth, 2007). Creative professionals and their talents are valuable organizational resources because professional service work faces high variability (Schmenner, 1986). For instance, working with clients with different wealth portfolios, earning potentials, and risk profiles, financial advising professionals with self-motivated creativity, strong adaptability, and systems understanding have been shown to outperform their peers (Quinn et al., 1996). This is because high variability naturally generates experiments that are conducive to more effective solutions by 
creative professionals. Individuals develop a deeper understanding of a problem as each unique case introduces variation into the problem statement (March, 1991; Weick, 1989).

Although knowledge creation resides in individuals, knowledge application is the primary responsibility of an organization (Grant, 1996b; Nonaka, 1994). Applying new ideas to create new practice areas therefore requires organizational support, cross-functional team knowledge integration and processes-oriented new service development practices (Anand et al., 2009; Froehle et al., 2000; Froehle and Roth, 2007; Gardner et al., 2012). Beyond organizational boundaries, changing needs of the clients, practitioner networks, and competition from other related professions also affect the development of new professional services (Anand et al., 2007; Harvey, 1992; Suddaby and Greenwood, 2001). The NSD and knowledge work literature has built a strong foundation for understanding the process that creates new professional service. However, how this process fits into knowledge application and the overall sequence of changes in professional work over time is under-studied. Filling this knowledge gap is particularly important in helping professions that are going through significant structural changes (Merritt, 2015; Susskind, 2013).

\subsubsection{Validation of Professional Service}

A profession is a community that possesses specialized knowledge and solves problems within a larger society that generally lacks such knowledge (Goode, 1957). Informed by their knowledge (including information, understanding and skills) obtained from years of training and practice, the professional independently develops the problem definition, which can in some instances diverge from that of the client. "In fact, the professional claims to be the most reliable authority on the nature of the reality it deals with.” (Freidson, 1970, p. xvii)

However, the professional rarely creates new services in isolation. Knowledge asymmetry often necessitates professional service innovations to be vetted by a third party, be it a research 
institution, government body, educational institution, consulting firm or professional association (Swan and Newell, 1995). Frequently, professional associations play important roles in endorsing new ideas (Goodale et al., 2008; Greenwood et al., 2002) and for setting work standards (Lummus, 2007). Validation by the professional association therefore also lends support to an individual professional's authority in problem definition and solution implementation especially when clients lack reliable means to evaluate the quality of the service outcome. Traditional fields of medicine, law and accounting have influential professional associations that sanction new services. In medicine new services are vetted by organizations such as the American Medical Association, which studies the various outcome measures regarding a particular innovation and makes recommendations regarding adoption (Eddy, 1990).

Consumers are increasingly turning to the market rather than a third party to validate service accreditation (Dellarocas, 2003), since ICT has greatly increased access to information and reduced knowledge asymmetry. In addition, firms are focusing increasingly on direct-to-consumer advertising in fields such as pharmaceutical drugs to help promote their products to consumers rather than solely to medical practitioners (Donohue et al., 2007). These changes in the marketplace are challenging the profession's exclusive control of its knowledge base (Greenwood and Lachman, 1996). Although some OM work has focused on the influence of professional associations or societies (Goodale et al., 2008; Greenwood et al., 2002), there remain considerable gaps in our understanding of how these important structures, along with the marketplace and ICT, influence the progression of professional work over time.

\subsubsection{Diffusion of Professional Service}

Professional bodies also play critical roles in articulating and amplifying the knowledge underlying the services (Nonaka, 1994). For instance, professional associations promote 
information that diffuses technological developments among their members (Swan and Newell, 1995) and helps shape norms of professional behavior (Goodale et al., 2008). This diffusion process may be slowed by the opposition of PSOs looking to protect the professional status of their membership. For example, in the field of law, standardized legal forms that help streamline the development of wills and contracts provide great value to clients at low cost. These forms, however, challenge the professional status of lawyers (Susskind, 2013), who may argue that failure to customize can lead to increased litigation. In spite of professional opposition, when service innovations provide value, they naturally diffuse and are adopted by service providers (Mansfield, 1968). Codifying professional knowledge has allowed online legal services such as LegalZoom to be highly competitive (Susskind, 2013). This strategy of codification versus personalization (Hansen et al., 1999) can help diffuse services to a wider audience.

Aside from economic factors, technology also facilitates diffusion, which can threaten the professional status of work by embedding knowledge in products or production processes (Ford, 2015). In medicine, for example, apothecaries and chemists became obsolete as modern day pharmaceutical companies used technology and applied the profession's knowledge base to mass produce drugs following a standardized process (see Abbott, 1988 page 146). ICT has promoted information sharing and improved diffusion as increased communication across populations increases adoption rates (Rogers, 2010). Furthermore, government agencies can aid the diffusion process (Walker, 1969) as they can require companies to provide lower cost service solutions or provide innovative solutions to pressing societal problems.

\subsubsection{Commodification of Professional Service}

On the surface, commodification is the opposite of customization. Similar to manufacturing settings where conformance contributes to high quality and lower cost (Kim et al., 2006, 1997), 
"hard baking” knowledge into protocols, document templates or computer programs achieves higher performance and cost efficiency. For example, the tax return service that accounting professionals have performed for decades has been replaced in part by software like TurboTax.

Over time, commodification can lead to more innovation by increasing the productivity of professional service work (Quinn et al., 1996; Schmenner, 2004). This is because commodification permits people with a lower level of skills - or even software programs - to do the work, and frees up individuals with a high level of expertise to specialize in the elements of work that do require customization. In essence, these individuals strive to come up with better ways to solve a client's problem by searching for new knowledge and/or experimenting with new delivery processes. Commodification coupled with customization can drive up both innovation and productivity (Schmenner, 2004). In the medical field for instance, technology can enable primary care physicians to take on more case management responsibilities and support the specialists to treat more patients (Harvey et al., 1993). For the clients to benefit from innovation as well as higher conformance quality at lower cost, better coordination and talent management is the key. The ongoing effort in the US to shift to coordinated population health management by groups of health care providers serves as a great example (Cimas, 2013).

\subsection{Applying a Life Cycle Model to Professional Service Work}

Life cycle theories have been adopted by various disciplines and remain one of the most common developmental models in management literature (Van de Ven and Poole, 1995). Models based on life cycles are uniquely suited for describing a unitary sequence of changes and for generating insights on how to manage the progression of a product (Levitt, 1965), service (Tax and Stuart, 1997) or organization (Chandler, 1962). For example, the well-known product life cycle framework describes the progression of a new product from introduction to growth, maturity, 
and decline (e.g., Day, 1981; Levitt, 1965). The key insight from the framework is that moving through each stage is associated with changes in the marketplace and therefore requires corresponding changes in promotional approaches and production strategies.

In services, cyclical models have been proposed to explain the dynamic process of service innovation in the context of new service development (NSD) (Johnson et al., 2000; Tax and Stuart, 1997). For example, Johnson et al. (2000) outlines the steps of the new service development process and the importance of enablers (e.g., Teams, Tools and Organizational Context). Tax and Stuart (1997) explains the stages of new service integration and suggests how to manage the planning cycle for the integration of new services into an operating service system. Although focusing exclusively on the NSD stage, these models have provided support for using life cycle models to explain the dynamic processes in services. We use this insight to develop a life cycle model of professional services in the green building industry by focusing on the market and technological forces that drive the evolution from innovation to commodification of LEED consulting work. Each iteration of the progression from customized to standardized work is highly time variant. Some professional services may take decades to progress, while others in their early stages of development may evolve rapidly. The iterations of the service work life cycle grow over time, which deepens the knowledge base and pushes the frontier of the profession.

\section{Method}

\subsection{Research Context: USGBC, LEED Rating Systems, GBCI and LEED Professionals}

Green or sustainable building is defined as the practice of creating and using healthier and more resource-efficient models of construction, renovation, operation, maintenance and demolition. ${ }^{\text {ii }}$ In the US, formal efforts to build green date back to the post-1970 energy crisis when the American Institute of Architects (AIA) formed an energy task force. The signing of the 
Declaration of Interdependence for a Sustainable Future in 1993 at the World Congress of Architects, a conference jointly held by AIA and International Union of Architects (UIA), officially put sustainability at the core of the professional practice and responsibilities. ${ }^{i i i}$

The United States Green Building Council (USGBC) was formed in 1993 to promote sustainability by transforming the way buildings, homes and communities are designed, built, maintained and operated. To this end, USGBC develops and updates the Leadership in Energy \& Environmental Design (LEED) rating systems (Table 1 lists the four generations of LEED rating systems). So far, there have been four iterations of LEED rating systems, resulting from the collective efforts from the green building professional community in pooling their knowledge and pushing the frontier of what the built environment can and should offer. As of January 2015, 3.6 billion square feet of building space were LEED-certified, with 2014 having the highest historical growth rate (http://www.usgbc.org/articles/green-building-facts).

$<$ insert Table 1 about here >

To become LEED certified, a building typically goes through a multi-year application process consisting of design, registration, construction and documentation, and accreditation approval. The Green Building Certification Institute (GBCI) was established in 2008 to administer certifications and professional accreditation within the framework of LEED green building rating systems. GBCI offers third party validation that building certifications and professional designations have met specific, rigorous criteria.

USGBC today has six chapters, 13,000 member companies and organizations, and nearly 200,000 professionals who hold LEED credentials (usgbc.org). These professionals help clients navigate the application process and score points in various green building categories as described in the LEED rating system. LEED consulting work thus includes the green building solution and 
associated application process. The solution varies in its level of sophistication depending on the target level of certification (i.e., LEED-certified, LEED-silver, LEED-gold, or LEED-platinum). Highly innovative building solutions typically require input from professionals with deep knowledge to achieve the points needed for higher levels of certification. The application process involves rigorous data and documentation management. LEED professionals must work with multiple stakeholders including the building owner, architect, engineer, interior designer, and general contractor, etc. throughout the multi-year process.

\subsection{Data Collection}

Our data consist of secondary sources including white papers, newspaper articles, LEED publications and primary qualitative data gathered via semi-structured interviews with 14 LEED accredited professionals (see A1 for background on informants). Questions revolved around the type of work the LEED professional engages in and how this work has changed over time. LEED professionals were purposefully sampled (Patton, 2002) to gather a range of perspectives among different types of LEED professionals (e.g., architects, engineers, interior designers) with varying levels of accreditations (e.g., LEED Green Associate, LEED AP). Forty-two percent of the interviewees are actively involved in USGBC/GBCI activities such as local chapter events, rating system development and LEED application review. We sought informants from varied backgrounds with deep knowledge of LEED and its component parts in order to reduce convergent retrospective sense-making (Eisenhardt and Graebner, 2007). Interviews were 54 minutes on average and were fully transcribed, resulting in a total of 534 pages of double-spaced text (102,873 words). The first author acted as the primary interviewer while the second author listened in and asked probing questions. The third author did not participate directly in the interviews but had access to both the digital recordings and transcripts. This approach of incorporating multiple 
investigators provided unique perspectives that aided in the triangulation of our interpretations (McCutcheon and Meredith, 1993).

\subsection{Data Analysis}

Analysis of the qualitative data was conducted using standard qualitative protocols. Immediately following each interview, the first and second author discussed initial thoughts and wrote down key initial impressions of the conversation. After all interviews were transcribed the authors engaged in several rounds of independent, focused coding based on the literature and exploring the stages of the life cycle. Following coding the authors held extensive discussions around interpretation of the data and worked towards consensus regarding the life cycle stages and related data. The quotes presented here were edited to remove redundant statements or expressions to improve readability. To protect the anonymity of our informants, any information that might reveal their identity was removed or modified. In line with previous work (Yin, 1989), we present our findings in a detailed narrative style focused on a theorized storyline (Golden-Biddle and Locke, 2007). In favor of concise writing, we include limited quotations in the body of the text, in line with prior research (Bhakoo and Choi, 2013; Wilhelm, 2011) we provide representative statements in Table A.2.

\section{Findings}

In this section we synthesize the case evidence and secondary data on LEED professional service work. We first describe the evolution of the LEED knowledge base as embodied in the USGBC LEED rating systems and the technological drivers of the evolution. We then discuss associated changes in the LEED professional community and analyze the underlying tension of this evolutionary process. Lastly, we extract the dominant trend from the changes in knowledge and people, and propose a life cycle model of LEED professional service work. 


\subsection{LEED Knowledge Base}

\subsubsection{LEED Knowledge Base Creation and Growth Strategy}

The USGBC provides the organizational structure to house and grow the knowledge on building green. In March 2000, the LEED Version 1 (pilot) rating system for new construction was released. Significant growth of LEED knowledge has occurred since. Our interviewees who began their LEED consulting work in the early 2000s reminisced about the small size of the LEED V1 rating system, which fit in just three printed binders. This nascent knowledge base pooled green building practices contributed by professionals from a variety of fields related to green building, borrowing heavily from the established professions of architecture and engineering. A decade later, LEED consultants rely on extensive online resources to complete the application.

In developing the rating systems, USGBC relies on volunteer groups whose primary responsibility is the development, implementation of, and revisions to LEED rating system. A grass-roots consensus-building process remains the core strength of USGBC. These groups include the LEED Steering Committee (LSC), three subcommittees of the LSC, and six Technical Advisory Groups (TAGs) for the six credit categories. These TAGS draw on disciplines related to these six core categories: location and planning, sustainable sites, water efficiency, energy and atmosphere, materials and resources and indoor environmental quality.

The LEED Advisory Committee is an LSC subcommittee charged with advising staff and LSC on market and implementation-related issues. Its purpose is to provide expert feedback and insight on how the LEED rating system and related tools, resources, and programs affect the user experience and market uptake of LEED. As the LEED rating system continues to push innovation, the advisory committee aims to ensure market acceptance and adoption. This dual purpose 
acknowledges the tension between the marketplace readiness and LEED experts looking to push the envelope on innovation.

Several informants highlighted the LEED profession and its associated communities as the primary source of green building innovations, while USGBC organizes the Green Building knowledge. For instance,

I think this [new knowledge] is going to come from your engineers and your designers, your civil engineers, your structural engineers, your architects, those who are committed to building smart and sustainable. Now that's what it comes down to and that's where it started from, there was a passion in changing the way we design and build. - R9

Although US universities are among the early adopters of the LEED rating systems in campus buildings, they have lagged in contributing to the creation of the LEED knowledge base but focused more on LEED knowledge diffusion. Students joined force with USGBC to push institutions to embrace green building courses and programs. In short, the LEED knowledge base draws on multiple core disciplines, attracts support from multiple stakeholders and evolves through a grass-root consensus-building approach.

\subsubsection{LEED Knowledge Applied in Both Customized and Standardized Processes}

Building owners seeking LEED certification typically retain LEED consulting services to help them find the right solution and navigate the application process. Initially LEED professional services focused on the application process itself, navigating the unstructured and often time consuming tasks involved in the application process and coordination efforts. With newly emerging standards and limited formal accreditation processes, these consultants provided considerable value to clients interested in receiving LEED certification. Over time, the process knowledge was codified into an online platform, LEED Online, described by one of our informants.

The continual upgrades with LEED have made the documentation process much easier. There was a time when the documentation process was so tedious, and now, the process is much easier. They've got formulas for a lot. The documentation forms have simplified quite 
a bit of that process. When you were doing a LEED project - certainly in the very early stages of it - if you didn't have an experienced team or, at least, people that had gone through LEED training as representing each part of that team, it was almost impossible to navigate. $-\mathrm{R} 4$

In addition to process management, LEED professionals can maximize the service value for their client by providing solutions customized for the building project (Abbott, 1988; CarrSaunders and Wilson, 1933). Inherent high variability in the location and building characteristics allows experiments to explore more effective solutions (March, 1991; Weick, 1989), while high variability can also constrain the efficiency of the LEED project because the idiosyncratic nature disrupts smooth and even work flow (Schmenner and Swink, 1998). This tension between innovation (i.e., high effectiveness) and commodification (i.e., efficiency) therefore underlies the dynamic mix of customized and standardized processes in LEED services over time.

One example of standardized solutions is the USBGC's LEED volume program. This program pre-approves LEED prototype to help participants with branded multi-unit operation go through a streamlined application process. The USGBC describes the benefits of the program "as achieving certification faster and at a lower cost than with individual building reviews” (usgbc.org). Our informants also highlighted how these programs accelerate the diffusion of green building practices in industries such as retail banking.

Innovations arise in LEED when professionals build sustainable buildings that leverage unique locational characteristics. For example, the Living Building Challenge created by the USGBC and the Canada Green Building Council goes beyond LEED Platinum (highest level) requirements. It challenges designers to create buildings that generate all their own energy from renewable sources while addressing occupants' needs and remaining aesthetically pleasing. These innovations push the frontier of green building design and practice and help expand the knowledge base over time. Each consecutive LEED rating system incorporates new ideas pioneered by LEED experts, thus 
raising the bar for various LEED certification levels over time. In contrast with the efforts in green building innovations, the inertia of existing practice persists. The use of environmentally unsustainable materials persists. However, when new services or routines add value (as in the case of LEED volume and sustainable materials), PSOs with market acuity will adopt them to improve delivery and/or reduce costs. In other words, the LEED consulting work consists of both customized and standardized processes that are always in flux.

\subsubsection{Technology Enhances LEED Knowledge Creation and Application}

As alluded to earlier, LEED Online is a web portal based on codified knowledge that increases efficiency and streamlines the application. Tasks including electronic document storage and submission, payment, team collaboration and notification and credit tracking are now housed in a singular formalized online process. Informants overwhelmingly highlighted LEED Online's positive impact on process efficiency. Knowledge codified in routines of the online system has improved consistency and productivity.

One objection to such standardized processes is that they can threaten the creative status of the profession, making the work, in a sense, "less" professional. For example, an entry certification level (e.g., LEED-certified) can be achieved by a lower-skilled (or “less”) professional work force. Although this work still relies on knowledge embedded in the examples and templates in the LEED Online system, the process knowledge that was once idiosyncratic is now housed in technology rather than the professional themselves. Nonetheless, process standardization in LEED consulting work was a dominant trend expressed by our informants. For example, collaboration between Autodesk and USGBC has led to software programs that provide automated direct access from the design environment to LEED Online (http://www.usgbc.org/resources/autodesk-apps-leedautomation), further improving the efficiency of the application process. For example, 
I think the future of LEED and of green building is really focusing even more directly on the key metrics that we're looking for and automating all of that, so I can see a day where we're just tracking the data from the project and are able to certify it just through automated information that the building is providing to us. - R13

Such standardization necessitates shifting the source of value creation to solution generation. As a result of such shifts, professional status as a LEED consultant has become more complex and stratified over time. Examining the evolution of the professional community provides insight into these changes.

\subsection{Evolution of the LEED Professional Community}

\subsubsection{LEED Professional Accreditation}

The Green Building Certification Institute (GBCI) sanctions the LEED certified credentials of professionals. If we analyze the trends in these accreditations over the last two years (March 2013 through June $2015^{\text {iv }}$ ) represented in Figure 1 we find that inter-disciplinary specialties including LEED AP Homes and LEED AP ND accreditations have increased, up 70\% and 23\%, respectively. These specialties are newly established to meet market demand for green homes and neighborhoods. We also find increases in both LEED Green Associate (24\%) and LEED AP O+M (15\%). LEED Green Associate accreditation continues to grow, most likely because it requires the lowest level of expertise and is attainable to students upon entering the profession. The growing interest in building performance during operation may be responsible for the increase in the AP $\mathrm{O}+\mathrm{M}$ specialty. We also witness a decline in those acquiring specialties that are associated with established professional disciplines (e.g., architecture and interior design) including LEED AP BD+C (-20\%) and LEED AP ID+C (-23\%) with the largest base of accredited professionals.

$$
<\text { insert Figure } 1 \text { about here }>
$$

This trend is consistent with the increased rigor in LEED credentials highlighted by our informants, for example. 
I think the LEED AP is now legitimate. It wasn't legitimate, maybe ten years ago when the test was remarkably easy. They really put a lot rigor into that exam and you cannot pass that easily anymore. - R12

Before 2009, there was only a generic LEED Accredited Professional (AP) certification. Once certified, the credential was for life. As the knowledge base of the LEED professional has grown in size and complexity, so does the need to adjust the accreditation process and validation of its professionals. The USGBC instituted a new, tiered system of accreditations in 2009 that included LEED Green Associate and LEEP AP with specialty. The new credentials also add requirements including ongoing credential maintenance via class work, on the job experience or retesting.

The change in validation criteria demonstrates a maturing of the profession as specialties are defined and assessments of skill sets are standardized. Green building professionals we spoke to also stated that accreditation of LEED AP was becoming more commoditized and that the USGBC and GBCI reacted to this by shifting to a more rigorous accreditation processes. Validation of the LEED professionals’ work has also shifted over time as the process has become more streamlined with LEED Online.

\subsubsection{LEED Professional Community Development}

To encourage the diffusion and adoption of green building knowledge and practice, the USGBC maintains a network of local chapters and affiliates. The annual Greenbuild International Conference and Expo provides networking and learning opportunities for members and other stakeholders including government agencies, education institutions, non-government organizations, and supply chain and R\&D partners, etc. Among the key stakeholders, universities and the US government have been two important early adopters of LEED innovations (McGraw Hill, 2010). Several informants mentioned that the USGBC has been very successful in its Center for Green Schools programs. This program was developed to "drive the transformation of all 
schools into sustainable and healthy places to live, learn, work and play.” These programs have contributed to the high adoption rate of LEED standards on University campuses and the engagement of stakeholders including students, administrators, elected officials and communities. Moreover, graduates from architecture, design and engineer programs often consider pursuing Green Associate accreditation as a differentiator upon entering the work force. Developing these relationships helps cultivate a pipeline of new professionals to drive new innovation.

In addition to acting as a knowledge center for the professionals during the application process and solution creation, USGBC also actively promotes the services provided by its professional members. USGBC thus plays a central role in actively growing the community of LEED professionals by providing valuable services.

\subsubsection{Stratification and Specialization among LEED Professionals}

In the context of LEED, programs like LEED Online represent efforts to standardize toward higher performance by increasing consistency (Kim et al., 2006, 1997). These programs also enable professionals with lower skill levels to participate in creation. As a response to the commodification of the LEED service, the profession develops specialties with differentiated skills. Similar movement was observed in modern medicine that features super specialization (Gawande, 2002), that allows the specialists to reap the benefits of the experience curve. Therefore, stratified levels of LEED professionals have emerged.

Specialization is not only a critical mechanism for differentiation, but serves as a key driver of the ever-expanding knowledge base. While standardization enables automation and/or lower level professional workforce to deliver some services, specialization allows a highly professional workforce to focus on creative endeavors and ultimately drive the field forward. This trend is salient from the comments of our LEED informants. Standardization and specialization together 
drive rational resource allocation, which allows professionals to not only work at the frontier of the service that requires creativity and autonomy but satisfy the growing market demand for green building with good value. This progression benefits society by offering options that cost less, deliver high and consistent process quality, and continuously develop new solutions. In short, the overall trend in LEED professional services is that the tasks once considered highly professional shift down the professional continuum as knowledge diffuses and best practices become standard.

\subsection{The LEED Professional Service Life Cycle}

The LEED rating system has gone through four iterations. It is clear from the case evidence that several forces, both internal and external, drive the evolution of the LEED knowledge base and professional community, and ultimately the progression of professional service work in LEED consulting. The speed of ICT development and adoption strongly influences the rate of change. Value-based competition drives ICT adoption, which speeds up changes in the knowledge base and professional community. At the same time, it is imperative for the experts to pursue new ideas and validation from the field in order to create new competitive advantages. The dynamic balance between customization and standardization defines the progression from innovation, validation, diffusion, to commodification of professional service work. We therefore propose a life cycle model that describes the dominant trend in the LEED profession as a result of these forces (see

Figure 2). The progression path emerges from concerted efforts in knowledge creation and diffusion, professional stratification, process standardization and solution commodification. These concerted efforts are ultimately driven by various market demands that push the work through the life cycle stages. Figure 2 summarizes these demands and associated stages in generic terms, while detailing the specific drivers in the LEED context.

< insert Figure 2 about here > 


\subsubsection{Demands that Drive innovation in Continuous Cycles}

In the early days of LEED consulting, individuals who were passionate about green building worked with clients to design unique solutions that pushed the frontier of the profession. Individual creativity drove new knowledge creation and new professional service development. As time passed, demand for customized solutions requiring high levels of technical expertise helped maintain LEED professional service work and changes occurred both within the professional community and the knowledge base. In addition to the stratified LEED accredited professionals, USGBC created the LEED Fellows distinction for their exceptional contributions to the green building community as well as for their significant achievements among LEED professionals. Additionally, USGBC expanded its own knowledge base and helped supply new service knowledge via its committees composed of discipline (e.g., engineering, architecture) experts.

The tensions between the demands for innovative and commodified service are evident in our data. Commodification of existing processes and solutions enhances value for clients. However, without innovation feeding the knowledge base, the commodified work itself is no longer deemed professional as technology and outsourcing subsumes it. LEED services face this danger given that services once deemed innovative are now incorporated into standardized processes and building codes. As we highlighted earlier, specialization allows high-level professionals to transition out of commodified service work to focus on a new round of service innovation.

\subsubsection{Demands that Drive the Transition from Innovation to Validation}

Although innovative work nourishes the profession, knowledge asymmetry inherent in professional services demands mechanisms to assure that new services get vetted. The profession approves and sanctions what constitutes professional work and who is capable of completing it. In LEED this validation is conducted by the USGBC and GBCI and its various committees. At the 
individual project level, each building project must go through a rigorous multi-year process of registration, application and review before receiving LEED accreditation. Our informants unanimously agreed that any project aspiring for LEED accreditation must have LEED professionals on the project team. Both the LEED professionals and the LEED project accreditation are overseen by the GBCI.

At the rating system level, the USGBC follows formal consensus building procedures to ensure that new LEED rating system committees gather inputs from multiple stakeholders throughout the proposal, design and revision process. As a result of the continuous search for new ideas by these creative individuals, LEED has released four versions since 1998.

\subsubsection{Demands for Formalized Education, Testing and Accreditation to Drive Diffusion}

As validated knowledge grows, so do the market demands for formalized education, testing and accreditation. Respondents highlighted the increasing importance of accreditation.

So if you go out and apply for jobs in an architecture or engineering or interior design firm today, at least in a large firm, they're almost always going to say LEED AP preferred or required within the first six months of employment. - R1

Accreditation of professional LEED status has also evolved over time as the USGBC seeks to assure the market that professionals have the requisite skills and knowledge. These accreditations have become more rigorous and stratified as a result of changing work requirements through the life cycle.

Formal structures such as local chapters help distribute knowledge while committees such as the LEED advisory committee are tasked to engage various stakeholders. The annual Greenbuild Conference serves as a major event for all the stakeholders to connect and showcase the latest development. Further, the informants talked about how government and institutional clients as well as the end consumers drove the diffusion of green building LEED standards, particularly in 
the US. As the adoption rate grows, offerings compete on their value proposition to the clients. Solutions that outsource service work to lower cost alternatives or embed services in technology begin to emerge.

\subsubsection{Demands for Cost Effective Solutions that Drive the Transition to Commodification}

Process and solution standardization reduces the risk of LEED application and improves project management. This standardization helps LEED improve user-friendliness and increase adoption rates. Switching from paper filing to LEED Online is a great example of how ICT improves productivity through standardization and knowledge codification. The LEED volume program discussed earlier is one example that meets this demand for cost effective solutions. Moreover, ICT in professional services has advanced from data storage and programmed routines to enhanced reasoning and pattern recognition (Brynjolfsson and McAfee, 2011). As a result, ICT has profound effects on the emergent characteristics and interactions among various types of professional services (Roth and Menor, 2003).

First, customized solutions are increasingly performed by lower-skilled professionals aided by ICT. For example, a Green Associate now has access to many examples and templates through the Internet to provide her client with a customized solution toward LEED certification. The most innovative solutions, however, still require individual creativity. Our informants observed increasing variation in green building projects that require different types of LEED professionals with varying skill levels.

Second, professionals that have deep knowledge in their own specialty increasingly collaborate to create new ideas or improve the process (Rosenkopf and Nerkar, 2001). One example is the collaboration between USGBC and vendors to automate the information sharing between design software Revit and the LEED Online platform. These efforts to improve efficiency by 
incorporating increasingly sophisticated technology are changing the work of a LEED professional. These changes drive commodification and free up resources for the next iteration of innovation.

\section{Discussion}

In this section, we reflect upon three implications of a life cycle perspective that hold potential to enhance theory and practice in the broader domain of professional services. First, we believe that focusing on professional service work as the primary unit of analysis and viewing the work on a continuum from highly professional to less professional expands the horizon of PSOM. Second, professional services should be viewed as evolving through a dynamic cyclical process, from creative services requiring occupational discretion to standardized routines in each iteration. Third, our findings suggest that technology management should be an important focus of PSOs.

\subsection{Focusing on Professional Work as the Unit of Analysis}

We propose that professional work be viewed as a continuum that ranges from highly customized and "new" to more standardized and potentially commodified (Figure 3). ${ }^{\text {vi }}$ Although green associates can complete the coordination and documentation work to get a building LEEDcertified (i.e., the lowest certification level), LEED APs with deep knowledge in engineering or architecture are essential for achieving the LEED gold or platinum levels. Conceptualizing professional service work on a continuum ranging from highly professional to less professional aligns more closely with operation management's primary focus on processes. This approach allows for better resource allocation to match the right type of process (i.e., right level of professional service work) with client needs, thus addressing the critical constraint of "talent." Indeed, internal stratification naturally exists in professional services (Maister, 2007) and leveraging less professional work to support the highly professional work has been shown to increase value in both law and consulting (Lewis and Brown, 2012; Quinn et al., 1996). 
$<$ insert Figure 3 about here $>$

The professional continuum not only applies to individual professions but offers insights when viewed across industries. Atul Gawande (2012) states that highly trained professionals in elite kitchens are innovators in the field, much like research doctors who develop new procedures for improving patients' health. He argues for health care (a professional service) to learn from food

service (a mass service). That is, new ideas developed in upscale restaurants (research hospitals) filter down to casual dining restaurants (community hospitals) that apply highly standardized processes to execute flawless delivery at lower costs. We believe that a broadened view of professional service work opens up possibilities to build theories that unify the service domain by removing the artificial separation between services traditionally viewed as highly professional (e.g., health care) and those less so (e.g., hospitality).

\subsection{Professional Service Work as a Dynamic Process that Must Be Managed}

As service work progresses along the professional continuum, the PSO faces a mix of customized and standardized processes and solutions that are in constant flux. Effectively managing this dynamic mix requires a two-pronged approach: (1) standardize whenever there is a guideline for the task at hand (e.g., LEED online), and encourage professionals to capture what they learn and move new procedures into standardized knowledge when possible, and (2) motivate professionals to use their discretion in a way that aligns with the performance objective of the organization when uncertainty precludes clear guidelines (e.g., Innovation Category in the LEED certification point system). The mixed characteristic of service work at any given time reinforces that service commodification and service innovation are both important considerations when it comes to competitive advantage (Anand et al., 2009). 
PSOM must ensure that there is enough talent with just enough knowledge to complete the range of tasks. Two important components are essential to achieve this goal. First, because a profession is organized around the knowledge system it applies (Abbott, 1988), understanding where knowledge is created and how it is disseminated is critical. In terms of LEED professional services, our findings highlight that practitioners, rather than universities, are creators of service innovations. Are practitioner's better suited to innovate than academics or is there a fundamental disconnect between the academy and practice that needs resolving? The answers to such questions would shine light on how new service innovations enter and circulate through the life cycle. In addition to improving efficiency of delivering professional services, effective management of the commodified elements of professional work frees the professional to focus on the elements that require more creativity, customization, and autonomy.

Second, effectively managing tasks at various levels of the professional continuum during the life cycle requires careful process evaluation. A key internal driving force of the life cycle progression is the professional community that validates new ideas and generates guidelines for a particular service work. The percentage of practicing professionals conforming to the guidelines, however, may be rather low. For instance, Gawande (2002) noted that overall physician compliance with various evidence-based guidelines ranges from 20 to 80 percent. The life cycle model suggests that the resistance to standardization could result from professionals' unwillingness to relinquish autonomy. In highly professional service work that is fraught with uncertainty, there is clearly a role for "abiding-confidence in the know-how” (Gawande, 2002). Without careful evaluation, however, excess discretion can lead to unnecessary variability in the service process. For example, when orthopedic surgeons within a single hospital use several 
different brands of knee or hip prostheses and deliver almost identical clinical outcomes, they increase the cost of the operation without providing better care (Gawande, 2012).

Future research opportunities exist in exploring the natural tension between the profession's control of knowledge and the value-seeking marketplace. The profession needs to protect its knowledge and be allowed to perform professional work that is endorsed by its membership. The market, however, is constantly searching for more efficient and effective ways of meeting the underlying need. PSOs need to address this tension by dynamically balancing innovation and commodification. One potential lever is a continuous improvement infrastructure that aligns the purpose, process and people in an organization (Anand et al., 2009). Empirical testing of the continuous improvement infrastructure in professional services is a natural next step. For managers, a scorecard that monitors the changes in the people and process elements of the infrastructure could be very useful. Linking the data gathered through the scorecard with operational and financial performance of PSOs has potential to contribute to both theoretical and managerial insights.

\subsection{Technology-Driven Professional Service Work}

Technology will not replace professions but it will alter the type of work they engage in. Our case evidence has suggested that real-time performance monitoring through sensor technologies may replace the LEED application process in the future, thus fundamentally altering the nature of the LEED consulting work. Yet many PSOs are not prepared for more sophisticated technological applications capable of complex cognitive based tasks (Brynjolfsson and McAfee, 2012). According to a study examining 702 detailed occupations, $47 \%$ of the US labor force is at risk from computerization (Frey and Osborne, 2013). IBM’s Watson computer and CVS are poised to 
transform up of $22 \%$ of prescription transactions in the US market, no doubt disrupting the traditional work of the primary care physicians and pharmacists (Cha, 2015).

“Combinatorial innovation” that combines efforts of the human and machine skills will most likely lead to innovative scalable process improvements (Brynjolfsson and McAfee, 2012). Take for example, technology's support of the medical care provider. Computerized Physician Order Entry (CPOE) systems are shown to enhance patient care (Queenan et al., 2011) and technological devices, such as an insulin pump, allow instant access to codified expertise and free up physicians to tackle more complex problems. This is consistent with the finding that ICT can improve productivity when it becomes a part of the production process, while ICT that merely documents or collects information does not (Boone and Ganeshan, 2001). Future research of combinatorial innovations can benefit from a life cycle perspective. As ICT applications diffuse among PSOs, detailed task-level data and logs will become available for answering fundamental empirical questions, such as the actual level of variability in professional service work, and the relationship between autonomy and outcome. Additional value can be created by integrating appropriate ICT into processes according to the life cycle stage of service work. For highly innovative work, ICT assists creative individuals in various research and development activities (e.g., computer aided design) and enables collaboration (e.g., file sharing and teleconferencing). ICT can be particularly useful in tracking data related to the mix of customized and standardized processes and solutions over time and offer data mining opportunities to discover knowledge and improve operations (Bendoly, 2003; Jacobs and Bendoly, 2003).

\subsection{Limitations and Future Research}

We acknowledge the limitations of our "fruit fly" (Fine, 1998) approach in this single industry case study. Though we worked to stratify our sample, we spoke with a limited set of informants. 
Compared with professions such as health care and law, LEED consulting has a narrower service domain and benefits from the grass-root consensus-building approach led by a strong organization (USGBC). These trade-offs are necessary however because the fast-paced development of a vibrant professional service since its inception brings the major drivers of a life cycle model into focus. Also, given the nascent state of OM work in the domain of professional services, exploratory work examining novel frameworks or theoretical insights often takes this form (Karwan and Markland, 2006).

Future research can undoubtedly improve our life cycle model. Replicating the qualitative research approach in other professional services to allow for multiple industry comparisons is a natural next step toward higher generalizability. Further, as the knowledge about the professional service life cycle grows in depth and breadth, moderating factors will undoubtedly emerge. For example, special interest groups may favor certain innovative or commodified services and push for their adoption, while resisting others perceived to diminish their control. Services relying heavily on tacit knowledge are likely to face barriers during diffusion due to training difficulties, compared with alternatives that are explicit and more likely to produce reliable outcomes.

\section{Conclusion}

In proposing a professional service life cycle, we hope to contribute to an expanded view of professional services in both literature and practice. Our life cycle perspective highlights the importance of identifying the types of work an organization is engaging in and at what stage this work appears in the life cycle. It also sets the stage for viewing professional work as something that can be improved upon in terms of both efficiency and effectiveness by using OM concepts that have long been applied in other work realms. In this emerging stage of theory development in professional service management, we believe that focusing on the service work itself provides the 
field of operations management with a unique perspective that offers considerable opportunities for theorizing. No doubt some of the arguments that we make may meet resistance. As the field works through its own professional service life cycle to validate new theoretical perspectives, our greatest hope is that these ideas will make their way through the life cycle on their way to informing practice. 
Figure 1. The evolution of the global LEED professional community - changing composition and increasing stratification ${ }^{a}$

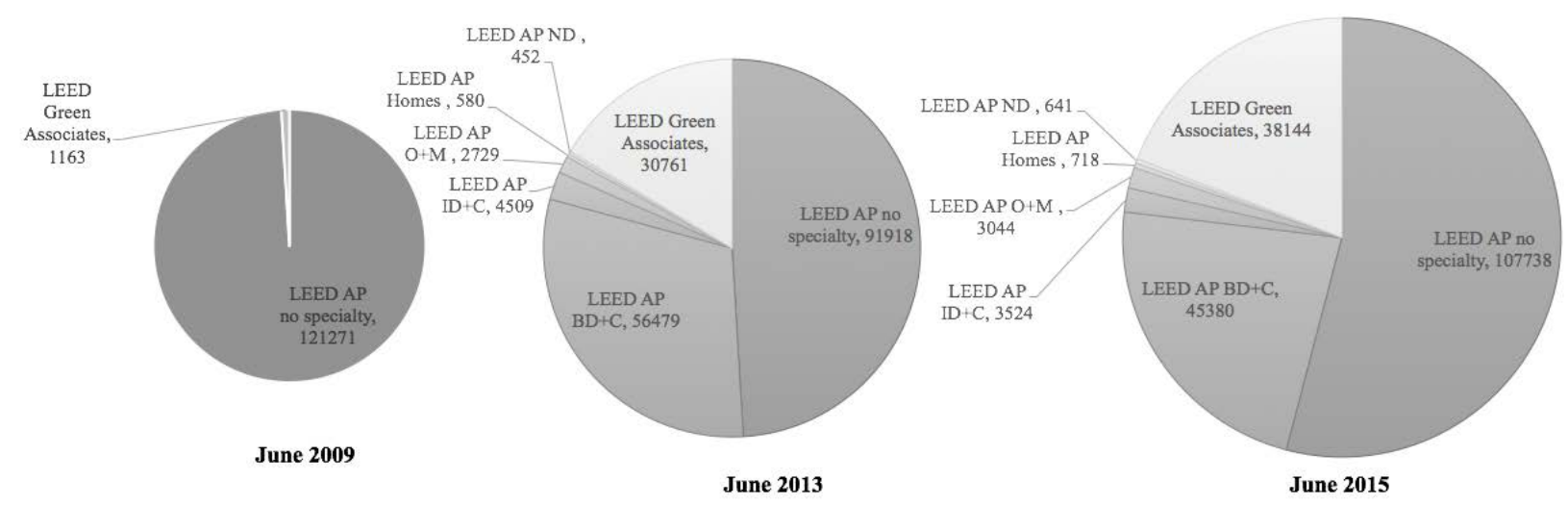

${ }^{\mathrm{a}}$ The authors created the graph based on following data sources: June 2009 data were collected from http://www.reallifeleed.com/2009/09/only-16-of-legacy-leed-aps-have-opted.html; June 2013 and June 2015 data were collected from http://www.usgbc.org/articles/leed-professionals-glance-july-2013 and http://www.usgbc.org/articles/leed-professionals-glance-june-2015, respectively. 


\section{Figure 2. The life cycle of a professional service and the specific demands in the context of LEED}

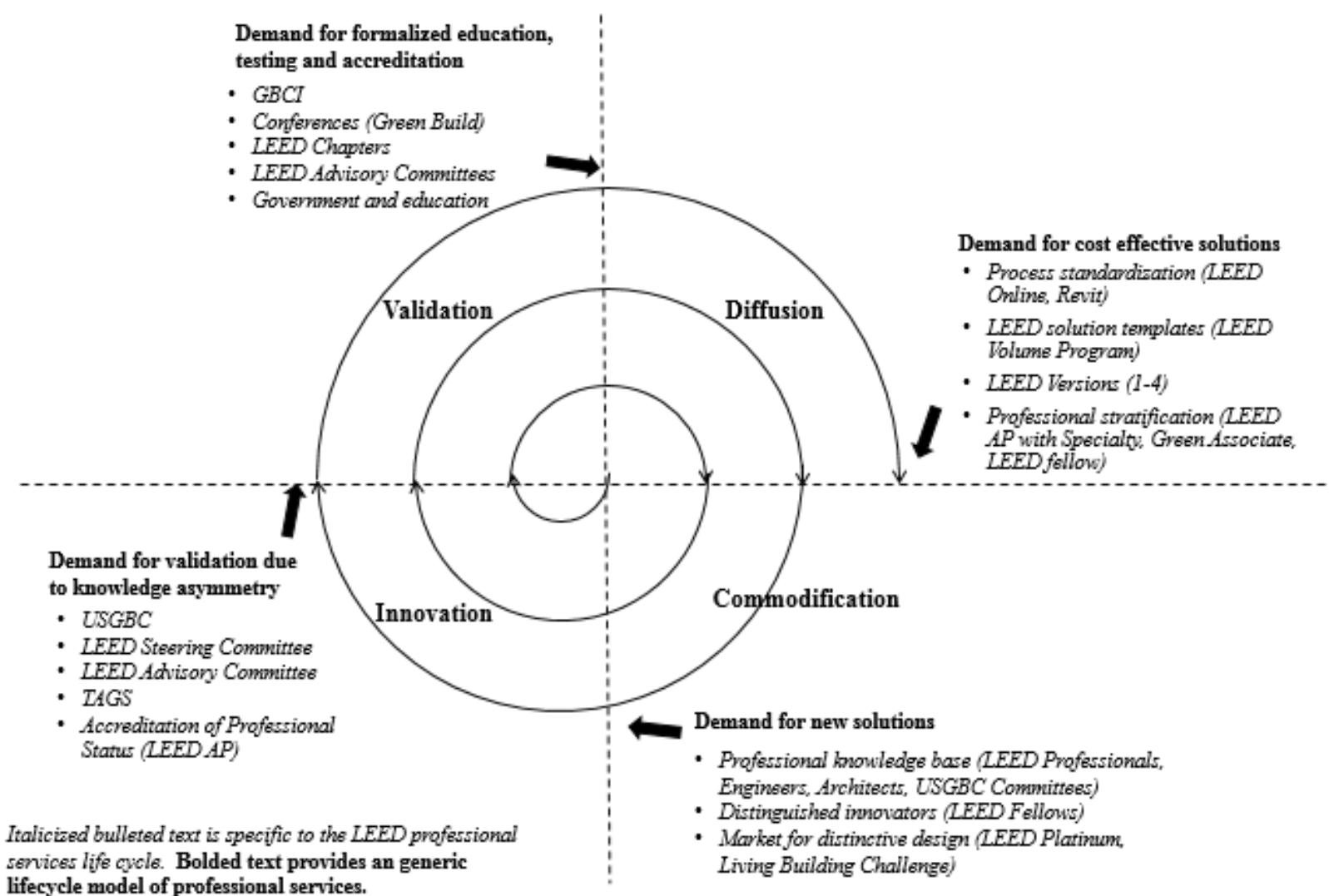


Figure 3. The professional continuum
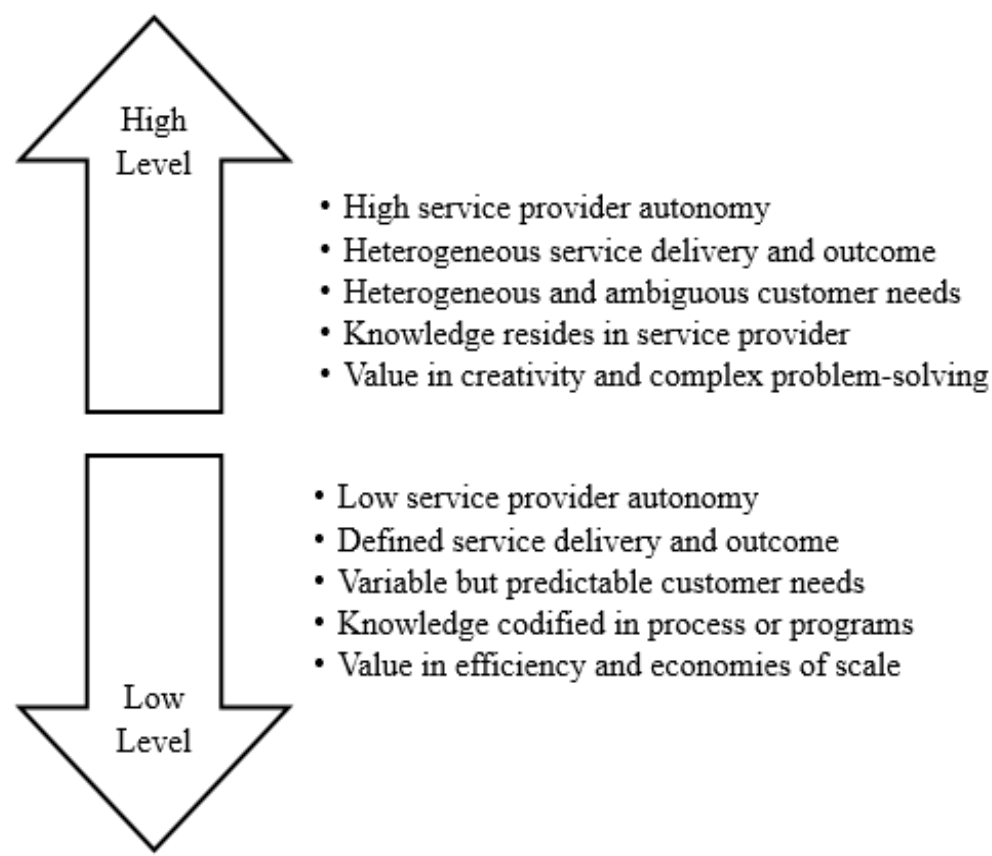
Table 1. A brief history of LEED through the four versions ${ }^{a}$

\begin{tabular}{|c|c|c|}
\hline $\begin{array}{l}\text { RATING } \\
\text { SYSTEM } \\
\text { (RELEASE } \\
\text { YEAR) }\end{array}$ & $\begin{array}{l}\text { MAIN FEATURES OF THE KNOWLEDGE } \\
\text { BASE }\end{array}$ & $\begin{array}{l}\text { CHANGES IN THE } \\
\text { PROFESSIONAL } \\
\text { COMMUNITY }\end{array}$ \\
\hline $\begin{array}{l}\text { V1 } \\
(1998)\end{array}$ & $\begin{array}{l}\text { - Keep simple and attainable cut out anything } \\
\text { already covered by US law. } \\
\text { - Launch LEED for New Construction (2000). }\end{array}$ & $\begin{array}{l}\text { Experts from architect, } \\
\text { engineering, interior } \\
\text { design, etc. pooled best } \\
\text { practice together }\end{array}$ \\
\hline $\begin{array}{l}\text { V2 } \\
(2001)\end{array}$ & $\begin{array}{l}\text { - Reflect leading building consultant practices } \\
\text { - Launch LEED for Core and Shell (2003), } \\
\text { LEED for Existing Buildings (2003), LEED } \\
\text { for Commercial Interiors (2004), and LEED } \\
\text { for Homes (2008) } \\
\text { - Launch LEED Online (2006) }\end{array}$ & $\begin{array}{l}\text { - } \quad \text { LEED no specialty } \\
\text { - Form GBCI to manage } \\
\text { professional } \\
\text { accreditation }\end{array}$ \\
\hline $\begin{array}{l}\text { V2009 } \\
(2009)\end{array}$ & 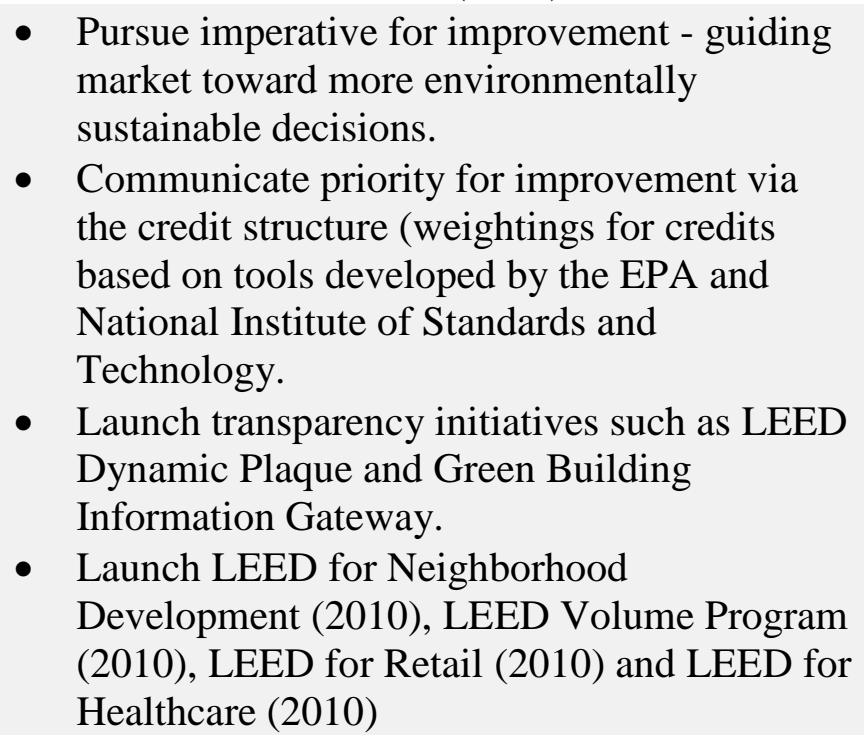 & $\begin{array}{l}\text { New in 2009: } \\
\text { - LEED no specialty } \\
\text { became the legacy } \\
\text { accreditation } \\
\text { - Added LEED credentials } \\
\text { with specialty } \\
\text { - Introduced LEED Green } \\
\text { Associate credential in } \\
2009 \\
\text { In 2011, GBCI introduced } \\
\text { LEED AP Fellows--the top } \\
\text { tier of the LEED Accredited } \\
\text { Professionals. }\end{array}$ \\
\hline $\begin{array}{l}\text { V4 } \\
(2013)\end{array}$ & $\begin{array}{l}\text { - Increase technical rigor } \\
\text { Facilitate expansion into new market sectors, } \\
\text { including data centers, warehouses and } \\
\text { distribution centers, hospitality, and midrise } \\
\text { residential structures. } \\
\text { - Award points for using products and materials } \\
\text { that have environmentally, economically and } \\
\text { socially preferable life cycle impacts (third } \\
\text { party certified). } \\
\text { - Streamline LEED Online. }\end{array}$ & \\
\hline
\end{tabular}

${ }^{\mathrm{a}}$ The authors developed the summary of main features in each LEED version and the changes in the professional community based on multiple USGBC official publications including USGBC website and white papers. 
Appendix A.1. Backgrounds of the informants.

\begin{tabular}{|c|c|c|c|c|c|}
\hline $\begin{array}{l}\text { INFORMANT } \\
\text { NO. }\end{array}$ & GENDER & PRIMARY TRAINING & $\begin{array}{l}\text { LEED } \\
\text { STATUS }\end{array}$ & $\begin{array}{l}\text { ACCREDITED } \\
\text { IN (YEAR) }\end{array}$ & $\begin{array}{l}\text { LEED WITH } \\
\text { SPECIALTY }\end{array}$ \\
\hline Rl & Female & Hospitality & $\begin{array}{l}\text { Green } \\
\text { Associate }\end{array}$ & 2009 & No \\
\hline R2 & Female & Interior design & AP & 2008 & Yes \\
\hline $\mathbf{R} 3$ & Male & Mechanical engineering & $\mathrm{AP}$ & 2001 & Yes \\
\hline R4 & Male & Green manufacturing consultant & $\mathrm{AP}$ & 2009 & No \\
\hline R5 & Female & Sustainable facility management & AP & 2008 & Yes \\
\hline R6 & Male & Architect & AP & 2003 & Yes \\
\hline R7 & Female & Textile manufacturer & AP & 2008 & No \\
\hline R8 & Female & $\begin{array}{l}\text { Environmental scientist + design (architect \& } \\
\text { green infrastructure) }\end{array}$ & AP & 2006 & Yes \\
\hline R9 & Female & Interior design & $\mathrm{AP}$ & 2008 & No \\
\hline Rl0 & Male & Construction engineering/management & AP & 2008 & No \\
\hline Rll & Male & Engineer & AP & 2003 & Yes \\
\hline R12 & Male & Architect & $\mathrm{AP}$ & 2003 & Yes \\
\hline R13 & Male & Mechanical Engineer & $\mathrm{AP}$ & 2009 & Yes \\
\hline Rl4 & Female & Architect & $\mathrm{AP}$ & 2003 & No \\
\hline
\end{tabular}




\section{A.2. Representative statements on the primary components of professional service work}

\begin{tabular}{|c|c|}
\hline & Representative statements \\
\hline \multirow{5}{*}{ 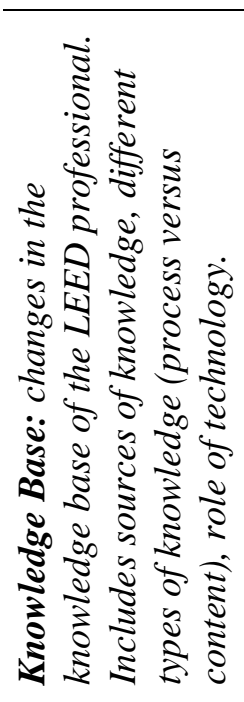 } & $\begin{array}{l}\text { Sustainability experts in built environments are pushing the envelope and going beyond what our current technology will allow and stretching } \\
\text { that technology and then reaching out to manufacturers and companies that can do the real research on how to get there. LEED Online has } \\
\text { made it dramatically easier. In the early years of submitting your LEED documentation, you literally sent books of physical paperwork to } \\
\text { USGBC. Now we have the LEED Online process so everything is submitted electronically. They've got samples or required formats that you } \\
\text { send it in. - R2 }\end{array}$ \\
\hline & $\begin{array}{l}\text { The dynamic really is if we make the next version of LEED too easy, then we get a larger market share, but we don't really address the issues } \\
\text { and our mission as much as we want because the rating system isn't affecting as much environmental change. If we make the rating system } \\
\text { too hard, then the market won't adopt it, and we also won't meet our mission, which is transformation, so it's really trying to strike the right } \\
\text { balance between pushing the [green building] industry but not pushing them so far that they abandon LEED. - R13 }\end{array}$ \\
\hline & $\begin{array}{l}\text { We're almost like an accountant. Very standardized. It's about making sure everything's in the right place and everything is filled out } \\
\text { correctly. - R1 }\end{array}$ \\
\hline & $\begin{array}{l}\text { It's almost like auditing, where you have to keep track of everything that's happening. All the materials that come onsite, if they're going for } \\
\text { the materials and resources credits, you have to see where they came from, trace all of that...It's almost like accounting. - R10 }\end{array}$ \\
\hline & $\begin{array}{l}\text { Previously we [USGBC] were requiring a lot of things that were unique to LEED, and what we've done with the most recent versions of our } \\
\text { rating system is really try to understand what typical construction projects are already producing in terms of documents and just asking for } \\
\text { certain documents that can prove that they've done certain things. So that paperwork burden is hopefully decreasing a little bit, which is also } \\
\text { another reason that the LEED consultant's role is sort of getting reallocated amongst the design firms or the construction firms. - R13 }\end{array}$ \\
\hline \multirow{4}{*}{ 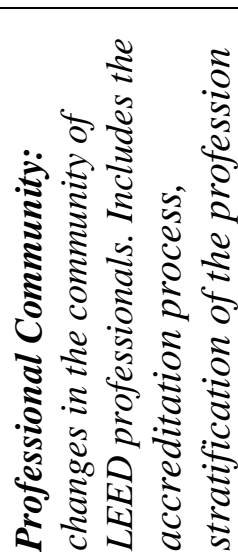 } & $\begin{array}{l}\text { I think trade shows are a big part of it, getting together with your colleagues in the industry and hearing what they're doing, being involved in } \\
\text { organizations like USGBC and staying involved, actively involved in those organizations. - R7 }\end{array}$ \\
\hline & $\begin{array}{l}\text { USGBC has a whole resource database... for designers, architects, engineers... anybody could find you in there and call you up for services. } \\
\text { - R1 }\end{array}$ \\
\hline & $\begin{array}{l}\text { We send people to the Greenbuild Conference. I've been highly involved with USGBC for a long time now. I was president of the Georgia } \\
\text { Chapter and then I was on the national board for a few terms so we volunteer for the USGBC. We go to their conferences. - R3 }\end{array}$ \\
\hline & $\begin{array}{l}\text { After 2008, LEED accreditation went through the GBCI, a big change. And the process became much more difficult. When I took it, it was } \\
\text { take a test and get certified. And I'm a lifelong student. I could take a test and get certified with relative ease. After that, they added an } \\
\text { experiential component to it. So now you have to take a test to become a Green Associate, which is like the first step. Then you have to have } \\
\text { experience working on LEED projects for X number of years before finally you become a LEED AP. So I think they wanted to make it more } \\
\text { rigorous. They wanted to pack more punch - so that when you said that this is who you were, people - your clients would trust it more. - R10 } \\
\text { I think the USGBC would be super excited if a LEED building kind of became standard and became normal and we were working to reach } \\
\text { beyond that and what is the next thing and how do we do more. - R2 }\end{array}$ \\
\hline
\end{tabular}




\section{A.3. Representative statements on the demands that drive the transitions in the life cycle of professional service work}

\begin{tabular}{|c|c|}
\hline & Representative statement \\
\hline \multirow{7}{*}{ 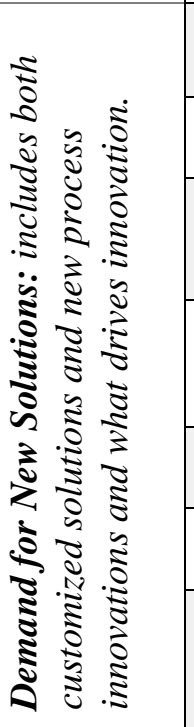 } & $\begin{array}{l}\text { But their [USGBC’s] philosophy has always been “everything has to be green.” I think those people are so passionate about just making the } \\
\text { world a better place. I don’t think they really care if } 10 \text { years from now the organization is obsolete. That means they met their mission. - R3 }\end{array}$ \\
\hline & $\begin{array}{l}\text { LEED had been very transformative to the market in that it put out a lot of ideas that have become standard practice in the construction industry, } \\
\text { but a lot of those ideas have become so standard that they weren't really innovative anymore. - R13 }\end{array}$ \\
\hline & $\begin{array}{l}\text { One of the things that LEED does is they always allow for open credits where you can propose things that you're doing that it's like tell us what } \\
\text { you're gonna do and you can get points for it based on your level of innovation. So I think that as people have been doing that, they're gaining } \\
\text { knowledge about innovative practices. And maybe with each version, they're incorporating the things that they're learning along the way. - R10 }\end{array}$ \\
\hline & $\begin{array}{l}\text { I would suspect in ten years all of our projects will be regenerative process. Right now we're focusing building less bad, that's the best way to } \\
\text { describe it. At some point in time technology, behavior change, and understanding of how our buildings actually work will allow regenerative } \\
\text { buildings that produce clean water, that produce clean energy, that can feed back into a grid, help them achieve net zero. - R6 }\end{array}$ \\
\hline & $\begin{array}{l}\text { Architects and engineers, mostly mechanical engineers, were really the first ones and were heavily involved in the process and had the } \\
\text { knowledge that drove it forward. Architects and mechanical engineers were the first to get most heavily involved. - R1 }\end{array}$ \\
\hline & $\begin{array}{l}\text { Clients that want to have sustainable conventions and want to know their carbon footprint. And then I think it's also just driven by some of the } \\
\text { people that are in that company that are just really passionate about it and care about it. - R3 }\end{array}$ \\
\hline & $\begin{array}{l}\text { I feel that it's like Windows. We get Windows } 98 \text { and then XP, and now we have Windows } 8 \text { and Windows } 10 \text { is coming out. I feel like it's } \\
\text { their way of trying to stay relevant and promoting new things. They're trying to be innovative and they're trying to incorporate new } \\
\text { technologies with each step. - R10 }\end{array}$ \\
\hline \multirow{4}{*}{ 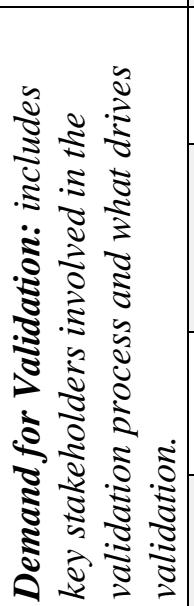 } & $\begin{array}{l}\text { Originally there was just a LEED AP credential. And then they took that credential and they blew it up into - it has an entry level credential } \\
\text { which is the Green Associate. It has all these different specialties of LEED AP. In some ways they were seeing such a vast number of people } \\
\text { take that credential that they felt like it was cheapening what the credential stood for. - R8 }\end{array}$ \\
\hline & $\begin{array}{l}\text { I've had students tell me that flat-out they got the job because they had LEED AP. Others have said it has been a competitive advantage } \\
\text { for them and that was one of the reasons why they got the job. They had LEED green associate. More and more of the students here are } \\
\text { understanding it and it's a way that young professionals can get an accreditation on their business card or on their resume that is } \\
\text { meaningful. - R1 }\end{array}$ \\
\hline & $\begin{array}{l}\text { The technical content came from volunteers, who are technical experts in the industry and voted by their peers to the technical advisory groups } \\
\text { (TAGs). Each technical advisory group is responsible for the credits of their specialties, so like an energy TAG, a water efficiency TAG. And } \\
\text { so it relies on experts in the industry for the technical pieces of it through those TAGs. - R8 }\end{array}$ \\
\hline & $\begin{array}{l}\text { had a lot of government contracts. This was 2007, 2008. The economy was great. Going into 2009, 2010, the economy crashed and there } \\
\text { ren't a lot of people building. And the government contracts were the most attractive and most competitive contracts. - R10 }\end{array}$ \\
\hline
\end{tabular}




\begin{tabular}{|c|c|}
\hline \multirow{4}{*}{ 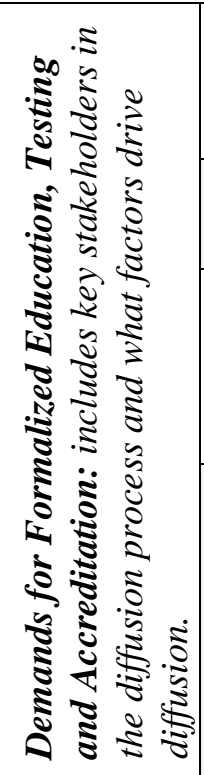 } & $\begin{array}{l}\text { They are now making the test even more difficult and complicated, and more stringent to get because what they want is to raise the profile of } \\
\text { the accredited professional because before you didn't have to have project experience in the beginning. Pre 2009, anybody could take the test } \\
\text { and study the material; you didn't need any relevant experience. Now they are trying to make it a more prestigious accreditation. - R1 }\end{array}$ \\
\hline & $\begin{array}{l}\text { Architects or engineering and design schools really work to integrate sustainable building into their curriculum and so that every architect and } \\
\text { every engineer is designing with those principles of a living building as the core concept. - R2 }\end{array}$ \\
\hline & $\begin{array}{l}\text { I think it started at the university level ... students were basically advocating their university leaders to build buildings that were more } \\
\text { environmentally responsible, and I think that universities had the ability and the opportunities to do that, so that's where a lot of the early } \\
\text { support came from. Beyond that I think a lot of individual corporations that shared a mission with USGBC then followed up and built green, so } \\
\text { NRDC [Natural Resources Defense Council], other nonprofits also pushed the envelope in terms of what they were building. - R13 }\end{array}$ \\
\hline & $\begin{array}{l}\text { You need it for your first gig, the first job in that industry...Back in 2001, when I got my LEED AP, there were maybe five of them in Texas } \\
\text { and now there are hundreds. So back then, it really stood out. Now, a lot of people have that on their card. And I think a lot of people } \\
\text { understand too that they have their LEED AP which is a great thing. It shows that they understand just sort of broad brush, the overall concept } \\
\text { but they may not necessarily have the expertise for the whole process yet... Originally there was just a LEED AP credential and in some ways } \\
\text { they were seeing such a vast number of people take that credential that they felt like it was cheapening what the credential stood for, which is } \\
\text { why they wanted to develop specialties so to really try and add a rigor around specific focuses. And then people could demonstrate and show } \\
\text { that they had a specific focus. - R8 }\end{array}$ \\
\hline \multirow{5}{*}{ 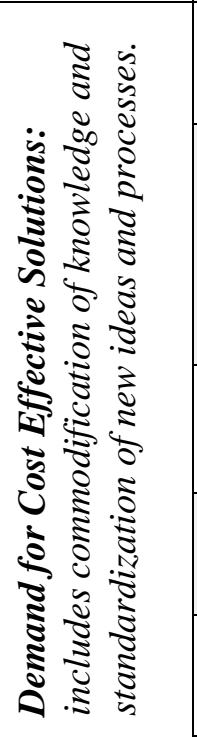 } & $\begin{array}{l}\text { The LEED volume program is a great example of repetition and being able to standardize. That has really helped a lot in the hospitality industry } \\
\text { the ability to roll things out because we work so much on brand standards and repeatable systems and processes that it's a common mindset. - } \\
\text { R3 }\end{array}$ \\
\hline & $\begin{array}{l}\text { One is where the administrator is in a very straightforward role and scope of work is that they're gathering the information together, } \\
\text { incentivizing the team to make choices that are better for the sustainability of the building as well as the credits that are applicable to that project } \\
\text { and kind of being a bit of a cheerleader as well as the person that comes down on them and says I really have to have this documentation. } \\
\text { There's the more aspirational projects that are reaching the LEED platinum and beyond and in those projects that sustainability or LEED expert } \\
\text { being a lot more innovation oriented and really helping that owner drive new ideas and exciting ways to create a building that isn't just meeting } \\
\text { LEED standards, but is taking the owner's goals and really stretching the team. - R2 }\end{array}$ \\
\hline & $\begin{array}{l}\text { What's really going to matter is that one of the guys who is coming out with the new software packages that generate automatically, based on } \\
\text { your set location and other factors, many of the LEED points right off the top... I think the fear of the green consultant is that software at some } \\
\text { level will reduce or speed up their work and therefore reduce their billable hours. - R12 }\end{array}$ \\
\hline & $\begin{array}{l}\text { LEED has produced a whole bedroom industry of people working in their pajamas, producing paperwork in the right format. So there's lot of } \\
\text { people out there who are competing on price based off that type of approach. And for the late adopters, they're the ones we're going to contract } \\
\text { with. Just get me my LEED plaque and make me change as little as possible.- R6 }\end{array}$ \\
\hline & $\begin{array}{l}\text { It's actually not just AutoCAD or Revit either -there are a handful of different vendors that the USGBC is trying to work with to automate } \\
\text { different parts of the LEED process. So it's a combination of USGBC technical staff and staff from that other company partnering and figuring } \\
\text { out how they can get their two platforms to talk.- R3 }\end{array}$ \\
\hline
\end{tabular}




\section{References}

Abbott, A., 1988. The system of professions: An essay on the division of expert labor. University of Chicago Press.

Anand, G., Ward, P.T., Tatikonda, M.V., Schilling, D.A., 2009. Dynamic capabilities through continuous improvement infrastructure. J. Oper. Manag. 27, 444-461.

Anand, N., Gardner, H.K., Morris, T., 2007. Knowledge-based innovation: Emergence and embedding of new practice areas in management consulting firms. Acad. Manage. J. 50, 406-428.

Bendoly, E., 2003. Theory and support for process frameworks of knowledge discovery and data mining from ERP systems. Inf. Manage. 40, 639-647.

Bhakoo, V., Choi, T., 2013. The iron cage exposed: Institutional pressures and heterogeneity across the healthcare supply chain. J. Oper. Manag. 31, 432-449.

Blackler, F., 1995. Knowledge, knowledge work and organizations: An overview and interpretation. Organ. Stud. 16, 1021-1046.

Boone, T., Ganeshan, R., 2001. The effect of information technology on learning in professional service organizations. J. Oper. Manag. 19, 485-495.

Brock, D., Powell, M., Hinings, C.R. (Eds.), 1999. Restructuring the professional organization: Accounting, health care and law, London. ed. Routledge.

Bronner, E., 2013. Law School's Applications Fall as Costs Rise and Jobs are Cut. N. Y. Times 13.

Brynjolfsson, E., McAfee, A., 2012. Winning the race with ever-smarter machines. MIT Sloan Manag. Rev. 53, 53-60.

Brynjolfsson, E., McAfee, A., 2011. Race against the machine: How the digital revolution is accelerating innovation, driving productivity, and irreversibly transforming employment and the economy.

Campbell, R.W., Been, V., Jackson, H., Willis, M., Haag, C.T., Keller, Z.A., Denman, H.L., 2012. Rethinking Regulation and Innovation in the US Legal Services Market. Issues 9, 1-70.

Carr-Saunders, A.M., Wilson, P.A., 1933. Professions. The Clarendon press, Oxford.

Cha, A.E., 2015. IBM Watson, CVS deal: How the smartest computer on earth could shake up health care for $70 \mathrm{~m}$ pharmacy customers. Wash. Post.

Chandler, A.D., 1962. Strategy and Structure: chapters in the history of the industrial enterprise. MIT press, Boston, MA.

Christensen, C.M., Anthony, S., 2004. Cheaper, faster, easier: Disruption in the service sector. Strategy Innov. 2, 56-65.

Cimas, R.J., 2013. Background and the Path to ACOs, in: Accountable Care Organizations: Value Metrics and Capital Formation. Productivity Press, pp. 1-24.

Cohn, J., 2013. The robot will see you now. Atl. Febr. 20.

Day, G.S., 1981. The product life cycle: analysis and applications issues. J. Mark. 45, 60-67.

Dellarocas, C., 2003. The digitization of word of mouth: Promise and challenges of online feedback mechanisms. Manag. Sci. 49, 1407-1424.

Donohue, J.M., Cevasco, M., Rosenthal, M.B., 2007. A decade of direct-to-consumer advertising of prescription drugs. N. Engl. J. Med. 357, 673-681.

Drucker, P., 1969. The age of discontinuity: Guidelines to our changing society. Harper and Row, New York.

Eddy, D.M., 1990. Practice policies: where do they come from? JAMA 263, 1265-1275.

Edvardsson, B., Olsson, J., 1996. Key concepts for new service development. Serv. Ind. J. 16, 140-164.

Eisenhardt, K.M., Graebner, M.E., 2007. Theory building from cases: opportunities and challenges. Acad. Manage. J. 50, 25-32.

Field, J.M., Xue, M., Hitt, L.M., 2012. Learning by customers as co-producers in financial services: An empirical study of the effects of learning channels and customer characteristics. Oper. Manag. Res. 5, 43-56.

Fine, C.H., 1998. Clockspeed:: Winning Industry Control in the Age of Temporary Advantage. Perseus Books. 
Ford, M., 2015. Rise of the Robots: Technology and the Threat of a Jobless Future. Basic Books.

Freidson, E., 1970. Professional dominance: The social structure of medical care. Transaction Books, New Brunswick, NJ.

Frei, F.X., 2006. Breaking the trade-off between efficiency and service. Harv. Bus. Rev. 84, 92-103.

Frey, C.B., Osborne, M.A., 2013. The future of employment: how susceptible are jobs to computerisation?

Froehle, C.M., Roth, A.V., 2007. A Resource-Process Framework of New Service Development. Prod. Oper. Manag. 16, 169-188.

Froehle, C.M., Roth, A.V., Chase, R.B., Voss, C.A., 2000. Antecedents of New Service Development Effectiveness: An Exploratory Examination of Strategic Operations Choices. J. Serv. Res. 3, 317.

Gardner, H.K., Gino, F., Staats, B.R., 2012. Dynamically integrating knowledge in teams: Transforming resources into performance. Acad. Manage. J. 55, 998-1022.

Gawande, A., 2012. Big med. New Yorker 13.

Gawande, A., 2002. Complications: A surgeon's notes on an imperfect science. Metropolitan Books, New York.

Golden-Biddle, K., Locke, K., 2007. Composing qualitative research. SAGE Publications, Incorporated.

Goodale, J.C., Kuratko, D.F., Hornsby, J.S., 2008. Influence factors for operational control and compensation in professional service firms. J. Oper. Manag. 26, 669-688.

Goode, W.J., 1957. Community within a community: the professions. Am. Sociol. Rev. 22, 194-200.

Grant, R.M., 1996a. Prospering in dynamically-competitive environments: organizational capability as knowledge integration. Organ. Sci. 7, 375-387.

Grant, R.M., 1996b. Toward a knowledge-based theory of the firm. Strateg. Manag. J. 109-122.

Grant, R.M., 1991. The Resource-Based Theory of Competitive Advantage: Implications for Strategy Formulation. Calif. Manage. Rev. 33, 114-135.

Greenwood, R., Lachman, R., 1996. Change as an underlying theme in professional service organizations: an introduction. Organ. Stud. 17, 563-572.

Greenwood, R., Suddaby, R., Hinings, C.R., 2002. Theorizing Change: The Role of Professional Associations in the Transformation of Institutionalized Fields. Acad. Manage. J. 45, 58-80. doi:10.2307/3069285

Hansen, M.T., Nohria, N., Tierney, T., 1999. What's your strategy for managing knowledge? Knowl. Manag. Yearb. 2000-2001.

Harvey, J., 1992. The Operations Management Challenge in the Delivery of Complex Human Services. Int. J. Oper. Prod. Manag. 12, 100-107.

Harvey, J., Lefebvre, E., Lefebvre, L.A., 1993. Technology and the creation of value in services: a conceptual model. Technovation 13, 481-495.

Hayes, R.H., 2002. Challenges posed to operations management by the "new economy.” Prod. Oper. Manag. 11, 21-32.

Hitt, M.A., Biermant, L., Shimizu, K., Kochhar, R., 2001. Direct and moderating effects of human capital on strategy and performance in professional service firms: A resource-based perspective. Acad. Manage. J. 44, 13-28.

Jacobs, F.R., Bendoly, E., 2003. Enterprise resource planning: developments and directions for operations management research. Eur. J. Oper. Res. 146, 233-240.

Johnson, S.P., Menor, L.J., Roth, A.V., Chase, R.B., 2000. A critical evaluation of the new service development process, in: Fitzsimmons, J.A., Fitzsimmons, M.J. (Eds.), New Service Development-Creating Memorable Experience. Sage Publications, Inc, Thousand Oaks, CA, pp. $1-32$.

Karwan, K.R., Markland, R.E., 2006. Integrating service design principles and information technology to improve delivery and productivity in public sector operations: The case of the South Carolina DMV. J. Oper. Manag. 24, 347-362. 
Kim, C.S., Spahlinger, D.A., Kin, J.M., Billi, J.E., 2006. Lean health care: What can hospitals learn from a world-class automaker? J. Hosp. Med. 1, 191-199.

Kim, K.Y., Miller, J.G., Heineke, J., 1997. Mastering the quality staircase, step by step. Bus. Horiz. 40, 17-21.

Levitt, T., 1965. Exploit the product life cycle. Harv. Bus. Rev. 43.

Lewis, M.A., Brown, A.D., 2012. How different is professional service operations management? J. Oper. Manag. 30, 1-11.

Lewis, M.A., Harvey, J., Heineke, J., 2013. Special Issue Call for Paper Professional Service Operations Management. J. Oper. Manag.

Lovelock, C.H., 1983. Classifying services to gain strategic marketing insights. J. Mark. 47, 9-20.

Lummus, R.R., 2007. The role of APICS in professionalizing operations management. J. Oper. Manag. 25, 336-345.

Maister, D.H., 2007. Managing the professional service firm. Free Press.

Mansfield, E., 1968. Industrial research and technological innovation; an econometric analysis.

March, J.G., 1991. Exploration and exploitation in organizational learning. Organ. Sci. 2, 71-87.

McCutcheon, D.M., Meredith, J.R., 1993. Conducting case study research in operations management. J. Oper. Manag. 11, 239-256.

McGraw Hill, 2010. Green Outlook 2011: Green Trends Driving Growth. McGraw Hill Construction.

Meisenhelder, S., 2013. MOOC mania. Thought Action 7.

Merritt, D.J., 2015. What Happened to the Class of 2010? Empirical Evidence of Structural Change in the Legal Profession. Empir. Evid. Struct. Change Leg. Prof. April 82015 Ohio State Public Law Work. Pap.

Nonaka, I., 1994. A dynamic theory of organizational knowledge creation. Organ. Sci. 5, 14-37.

Olson, E., Segal, D., 2014. A Steep Slide in Law School Enrollment Accelerates. N. Y. Times.

Papastathopoulou, P., Hultink, E.J., 2012. New Service Development: An Analysis of 27 Years of Research. J. Prod. Innov. Manag. 29, 705-714.

Patton, M., 2002. Qualitative research and evaluation methods. Sage Pubns.

Peteraf, M.A., 1993. The cornerstones of competitive advantage: a resource-based view. Strateg. Manag. J. 14, 179-191.

Queenan, C.C., Angst, C.M., Devaraj, S., 2011. Doctors' orders-If they’re electronic, do they improve patient satisfaction? A complements/substitutes perspective. J. Oper. Manag. 29, 639-649.

Quinn, J.B., Anderson, P., Finkelstein, S., 1996. Managing professional intellect: making the most of the best. Harv. Bus. Rev. 74, 71-80.

Roels, G., Karmarkar, U.S., Carr, S., 2010. Contracting for Collaborative Services. Manag. Sci. 56, 849863. doi:10.1287/mnsc.1100.1146

Rogers, E.M., 2010. Diffusion of innovations. Simon and Schuster.

Rosenkopf, L., Nerkar, A., 2001. Beyond local search: boundary-spanning, exploration, and impact in the optical disk industry. Strateg. Manag. J. 22, 287-306.

Roth, A.V., Menor, L.J., 2003. Insights into service operations management: a research agenda. Prod. Oper. Manag. 12, 145-164.

Schmenner, R.W., 2004. Service Businesses and Productivity. Decis. Sci. 35, 333-347.

Schmenner, R.W., 1986. How can service businesses survive and prosper. Sloan Manage. Rev. 27, 21-32.

Schmenner, R.W., Swink, M.L., 1998. On theory in operations management. J. Oper. Manag. 17, 97-113.

Suddaby, R., Greenwood, R., 2001. Colonizing knowledge: Commodification as a dynamic of jurisdictional expansion in professional service firms. Hum. Relat. 54, 933-953.

Susskind, R.E., 2013. Tomorrow’s lawyers: An introduction to your future. Oxford University Press Oxford.

Swan, J.A., Newell, S., 1995. The role of professional associations in technology diffusion. Organ. Stud. $16,847-874$.

Tax, S.S., Stuart, I., 1997. Designing and implementing new services: the challenges of integrating service systems. J. Retail. 73, 105-134. 
Van de Ven, A.H., Poole, M.S., 1995. Explaining development and change in organizations. Acad. Manage. Rev. 20, 510-540.

Von Nordenflycht, A., 2010. What is a professional service firm? Toward a theory and taxonomy of knowledge-intensive firms. Acad. Manage. Rev. 35, 155-174.

Walker, J.L., 1969. The diffusion of innovations among the American states. Am. Polit. Sci. Rev. 63, 880-899.

Weick, K.E., 1989. Theory construction as disciplined imagination. Acad. Manage. Rev. 14, 516-531.

Wilhelm, M.M., 2011. Managing coopetition through horizontal supply chain relations: linking dyadic and network levels of analysis. J. Oper. Manag. 29, 663-676.

Xue, M., Field, J.M., 2008. Service Coproduction with Information Stickiness and Incomplete Contracts: Implications for Consulting Services Design. Prod. Oper. Manag. 17, 357-372. doi:10.3401/poms.1080.0024

Yin, R.K., 1989. Case Study Research: Design And Methods. Sage Publications, Thousand Oaks, CA.

${ }^{\mathrm{i}}$ The first general topic to be covered by the Journal of Operations Management is: Operations processes in manufacturing and service organizations (http://www.journals.elsevier.com/journal-of-operationsmanagement/). Therefore, both customized and standardized processes need to be examined to maximize the efficiency and effectiveness of professional service operations.

ii http://www.epa.gov/greenbuilding/

iii http://server.uia-architectes.org/texte/england/2aaf1.html

iv USGBC publishes summary data on the LEED professionals every two months since March 2013 in articles such as: http://www.usgbc.org/articles/leed-professionals-glance-june -2015. The six LEED AP specialty categories are: Building Design + Construction for design and construction phase (BD+C), Operations + Maintenance $(\mathrm{O}+\mathrm{M})$, Interior Design + Construction (ID+C), Neighborhood Development (ND) and Homes

${ }^{v}$ http://www.centerforgreenschools.org/our-story.asp

vi We acknowledge that other operations models have categorized services, usually by industry, along these dimensions, however, those models have not focused on the nature of the individual "unit" of work as the unit of analysis, nor have they described a continuum of work performed by individuals. 